\title{
The Impact of Socioeconomic Factors on Tuberculosis Prevalence in Latvia
}

\author{
Andrejs Ivanovs ${ }^{1, *}$, Ieva Salmane-Kulikovska ${ }^{2}$, Ludmila Viksna $^{3}$ \\ ${ }^{1}$ Statistics Unit, Riga Stradins University, Latvia \\ ${ }^{2}$ Department of Internal Diseases, Riga Stradins University, Latvia \\ ${ }^{3}$ Department of Infectology and Dermatology, Riga Stradins University, Latvia
}

Copyright $\odot 2016$ by authors, all rights reserved. Authors agree that this article remains permanently open access under the terms of the Creative Commons Attribution License 4.0 International License.

\begin{abstract}
Tuberculosis (TB) is commonly linked to poverty, overcrowding and malnutrition. It was known earlier that TB more frequently attacks the most vulnerable part of the society - people who have lower socioeconomic status and harmful habits. Being aware of determinants of TB, attenuation of morbidity can be accomplished. This paper identifies impact of socioeconomic risk factors and risk conditions on prevalence of TB in Latvia, using the Four Layers of Health Determinants Model. The impact of risk factors and risk conditions is analysed in two levels individual and societal. The results of the study show that the strongest risk factors and risk conditions are HIV positive, homelessness, experience of imprisonment and underweight. BMI, drug abuse and unemployment are the strongest TB predictors. TB prevention programmes should be redesigned to involve additional factors that may contribute to the onset of TB.
\end{abstract}

Keywords Tuberculosis (TB), Risk Factors, Risk Conditions

\section{Introduction}

Tuberculosis (TB) is a bacterial disease that most commonly affects lungs. Bacillus Mycobacterium tuberculosis causes TB in humans. Infection mostly gets into human bodies with droplets as the result of the direct contact $[1,2]$. A person having TB annually infects 10 people; two out of them can develop active form of TB [3].

Despite the medical progress and social policies, TB is an outstanding problem and remains a widespread disease of the World. According to the World Health Organization (WHO), 8.6 million people in the World fell ill with TB in 2012 (1.4 mill. died) [4], 9.0 million people - in 2013 (1.5 mill. died) [5], but 9.6 million people - in 2014 (1.5 mill. died) [6].

$\mathrm{TB}$ is the second most important cause of death following
HIV/AIDS. 95\% of TB's deaths occur in countries of low or moderate income level. During the period from 1990 to 2012, the world mortality from TB has declined by $45 \%$ [7]. The WHO Assembly resolution declared TB as a worldwide public health problem in 1991 [8].

Since 2001 epidemiological situation of TB in Latvia has generally improved - morbidity has declined; however, in 2012 morbidity increase in Latvia was registered - 43.0 cases per 100,000 inhabitants. In 2013 morbidity decreased again, amounting to 38.3 cases per 100,000 inhabitants, but in 2014 the morbidity rate continued to decrease to 31.8 cases per 100,000 [9]. Quality treatment (DOTS) and diagnostics options, reimbursed by the State, are available for the population in Latvia. Despite that, TB morbidity rates in Latvia are still among the highest in Europe, leaving behind only Lithuania and Romania.

Historically, TB was attributed to as a social disease [10]. TB is commonly associated with poverty, overcrowding, malnutrition, immigration, HIV, alcohol, or drug use and other factors [2], so TB is not only a medical problem, but the result of social problems in the society [11]. By reducing the impact of these determinants, prevalence of TB in the country can be decreased.

Historical examples show the importance of TB determinants - during the second half of the $19^{\text {th }}$ century and the first half of the $20^{\text {th }}$ century, before the TB treatment methods were discovered, morbidity and mortality caused by TB in European countries continuously decreased. The decrease was associated with isolation of TB patients in sanatoriums and hospitals [12] and also with improvement of housing conditions, food quality and access to clean water for everyday needs [13].

Most of the focus of TB elimination programmes is on new medicines or improvement of BCG vaccine, however, it is rather a struggle with consequences than with causes. In order to reduce prevalence of TB, it is necessary to develop and implement a wide range of TB eradication programmes that acknowledge macro and micro level risk factors of TB, as well as risk conditions that affect these risk factors. In 
order to find causes of TB, focus should be on determinants of the disease or risk factors. Risk factors, are human traits or characteristics, or the impact on human health, which increases the likelihood of developing a disease or get injuries" [14]. A risk factor does not cause TB, but increases probability of developing TB.

The Four Layers of Health Determinants Model, presented by Swedish scientists G. Dahlgren and M. Whitehead, is used to classify health determinants. This model divides determinants into four layers depending on their impact [15]:

The first layer. Socioeconomic, cultural and environmental conditions - development of the society, functioning of social institutions, political, cultural and economic characteristics, ecology;

The second layer. Living and working conditions housing, health care, water and sanitation norms, unemployment, working conditions, educational opportunities and food quality;

The third layer. Social and community networks relations between people;

The fourth layer. Individual lifestyle factors;

The core factors. Non-adjustable human biological risk factors - gender, age and constitutional factors that cannot be changed neither by individual himself, nor by factors from other levels.

The model not just classifies and analyses risk factors that directly increase risk of disease on the individual level, but also includes conditions that affect risk factors and have mediated impact on the disease - Risk conditions or Proximate risk factors. Risk conditions do not increase probability of developing TB directly, but implicitly affect risk factors, indirectly increasing the risk of disease via risk factors [16].

In the current study most important determinants of $\mathrm{TB}$ were identified and classified by summarizing information about most important disease risk factors and risk conditions, as well by exploiting the Four-layer model of health determinants.

1. First level - general socioeconomic conditions of the society, culture and environment:

1) Gross domestic product $[2,17]$ *;

2) Immigration processes $[18,19,20]$;

3) Urbanization $[2,13]$ *;

4) Incidence of TB in the country [10] *.

2. Second level - living and working conditions:

5) Poverty (income level) $[10,13,21]$;

6) Employment (unemployment) [13, 22, 23, 24, 25];

7) Housing conditions (overcrowding) [13, 22, 26, 27];

8) Homelessness [13, 23, 24, 28, 29];

9) Imprisonment [3, 22, 28, 29, 30].

3. Third level - psychosocial risk factors:

10) Social exclusion $[31,32,33]$;

11) Depression $[31,34,35,36,37]$.

\section{Fourth level - individual lifestyle risk factors:}

12) Smoking [3, 23, 38, 39, 40, 41];

13) Alcohol abuse [3, 39, 42];

14) Drug use $[22,29]$;

15) Malnutrition, Body mass index (BMI) [43, 44].

\section{Core - human biological risk factors:}

16) Gender [2, 13, 28, 29, 39];

17) Age $[13,39]$

18) HIV $[2,3,13,45]$;

19) Diabetes $[3,10,19,22]$.

Interaction and impact of $\mathrm{TB}$ risk factors and risk conditions within the framework of Four-layer health determinant model are illustrated in Fig. 1. Morbidity of TB is mostly developed by individual immunity disorders - due to low immunity level "sleeping" mycobacteria reactivates, or after contact with TB patient in active phase reinfection occurs, resulting in mycobacterial stress in body that cannot be tackled by the organism's immune system. Immune system disorders are caused by a number of risk factors of the third, the forth and the core level of the Determinant model - psychosocial risk factors (social exclusion and state of depression), individual lifestyle risk factors (addictions, malnutrition and BMI), as well as biological risk factors (gender, age, HIV and diabetes).

Biological risk factors could not be impacted by any risk conditions, but psychosocial and individual lifestyle risk factors are impacted by risk conditions of the first and second level - living and working conditions (socio economic status, imprisonment, housing, employment, homelessness) and general risk conditions (incidence of TB, immigration, urbanization, GPD).
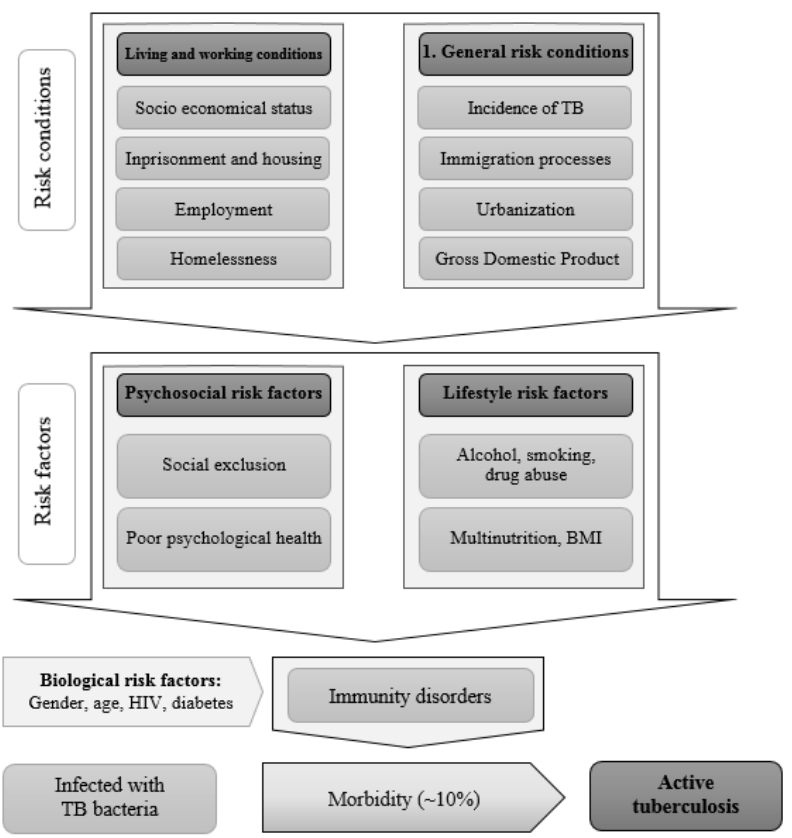

Figure 1. Scheme of TB risk factors and conditions

Prevalence of TB risk factors is affected by individual's living and working conditions (the second level) - low 
socioeconomic status, poverty, low-skilled job or lack of employment, poor housing conditions and imprisonment or homelessness. Risk conditions on the first level influence factors of the societal level - gross domestic product, immigration processes, urbanization rate and TB incidence in the society.

Prevalence of active TB impacts incidence of TB in the country, creating a vicious cycle - alongside with increase of morbidity, significance of this risk condition increases, influencing individual risk of infection and reinfection. Individual level consequences of TB negatively affect individual's socioeconomic and psychological status.

\section{Materials and Methods}

The study was carried out from August 2011 to December 2012 in the Tuberculosis and Lung Disease Centre of Latvia. The sample $\mathrm{n}=304$ enclosed TB patients. The questionnaire contained 196 questions about patients' income, health, unhealthy habits, daily nutrition, living conditions and employment, etc.

The aim of the study was to identify impact of the risk factors and risk conditions on prevalence of TB in Latvia. The Four Layers of Health Determinants Model, by G. Dahlgren and M. Whitehead was used as the basis of identifying risk factors and risks conditions. The impact of these factors was statistically tested, and the obtained results were compared with four nationally representative studies in Latvia.

The survey of the current study was designed to be statistically comparable to the study "Social Determinants of Health Behaviors. Finbalt Health Monitor" (Finbalt) that was made in Latvia in 2012. The sample size of the Finbalt study amounted to 3,004 inhabitants. The survey questionnaire contained questions about health, health care, nutrition, physical activities and addictions [46]. Most of the questions from the Finbalt study were also included in the survey that is on the basis of the current study, in order to obtain data for accurate comparison, i.e., binary logistic regression was implemented, using the data form the Finbalt study.

In addition, the date from "The European Union Statistics on Income and Living Conditions") (EU-SILC) in Latvia were used for characterizing economic and housing situation of TB patients in Latvia. EU-SILC is annual study of the housing conditions, economic situation and employment of the population; this study is implemented in all EU member states. In Latvia this study is regularly carried out by the Central Statistical Bureau. In 2012 the EU-SILC study involved 6,499 households and 12,964 individuals who were 16 years and older [47].

The current study also used the data from the study "Use of Addictive Substances among the Population in Latvia" (2011) for obtaining more information about use of drugs and other addictive substances in TB patients. The study "Use of Addictive Substances among the Population in
Latvia" by the Centre for Disease Prevention and Control employs a nationally representative sample of the Latvian population $-4,500$ respondents aged 15 to 64 years [48].

Date about social exclusion from the study in 2007 "Causes and Duration of Unemployment and Social Exclusion" were also used in the current study. The study "Causes and Duration of Unemployment and Social Exclusion" analyses determinants of the unemployment, as well as identifies and characterizes social exclusion risk groups. This study has a sample of 8,000 respondents who were interviewed face-to-face [49].

Four first level risk conditions were not included in the questionnaire due to the local nature of the survey, except for immigration processes that were redefined as the second level risk condition "born abroad". All other 15 risk conditions and risk factors of the second, third, fourth and core levels were included in the analysis; thus the impact of 16 potential risk conditions and risk factors was examined.

Odds Ratio (OR) was used to determinate individual risk of $\mathrm{TB}$ and Population attributable fraction $\left(\mathrm{PAF}^{1}\right)$ to determinate importance of risk conditions and risk factors of the societal level. PAF analyses what impact risk factors have on morbidity of the total population of the country, even in cases when risk potential is low. Therefore, it is preferable to calculate not just the risk odds ratio, but also $\mathrm{PAF}$, in order to obtain data about risk factor prevalence in the population $[3,10]$.

Spearman correlation test was used to determinate interrelation between two variables. Pearson's Chi-square test was used to evaluate differences in categorical study data. All data having statistically significant differences $(p<0.05)$ between TB and non-TB groups of respondents were used as predictors in the binary logistic regression. The fact of having TB (1) or not having TB (0) is defined as the dependent variable. As risk predictors, the following psychosocial, lifestyle and biological variables are selected: smoking, use of alcohol and soft drugs (hashish and cannabis), psychological health, breakfast skipping habit, BMI, gender and age. HIV status, homelessness, imprisonment experience and housing conditions were not included in the model due to absence of these risk conditions in the nationally representative study that was used for modelling (Finbalt). Wald statistics, used in binary logistic regression assessed the impact of the predictors.

Linear regression assessed the impact of predictors on the linear dependent variable - BMI. Age, gender, income level, unemployment and food consumption were selected as predictors of BMI.

\section{Results and Discussion}

\footnotetext{
${ }^{1}$ Population attributable fraction $=($ prevalence $\times($ relative risk -
} $1)) /($ prevalence $\times($ relative risk +1$))[3]$ 


\subsection{Living and Working Risk Conditions}

The results show that $12.0 \%$ of TB patients are born outside Latvia, and this is similar to the general population data - according to the Central Statistical Bureau of Latvia $14.6 \%$ of the residents of Latvia are born outside Latvia $(p=0.257)$. Risk calculation shows that being born abroad is not a statistically significant $\mathrm{TB}$ determinant $(\mathrm{OR}=0.80$, $95 \% \mathrm{CI}=0.6$ to $1.1, \mathrm{p}=0.225$ ), so people born outside Latvia do not have higher risk of developing TB than those who were born in Latvia. It is possible that lack of statistical significance of this risk condition is associated with comparatively low immigration rates in Latvia, where population migration rates are considerably higher. It must also be noted that almost all respondents were born in the Soviet Union, and those who were born abroad arrived in Latvia during the Soviet period and have lived in Latvia for at least 20 years. Countries in which these people were born had equal TB control strategies, similar disease tendencies and treatment options, thus the fact the person was born in other country is not relevant in relation to the onset of the disease in Latvia, as it has been reported in other countries $[18,19,20]$. This risk factor is not statistically significant also in Estonia, where the situation with the number of immigrants is similar to the situation in Latvia - OR $=0.68$ [23].

Family income of TB patients per family member (USD $0-200)$ is lower than the average income per family member in Latvia $(19.2 \%, \mathrm{p}<0.001)$. The results show that persons with monthly income level of USD 0-200 per family member have 6.8 times higher risk of developing TB than people with higher income $-\mathrm{OR}=6.82(95 \% \mathrm{CI}=5.1$ to 9.1 , $\mathrm{p}<0.001)$. These results are consistent with other studies' results $[10,13,21]$, pointing to TB as the disease of the poor.

There are more unemployed persons among TB patients $(41.2 \%)$ than among the general population - $13.1 \%$, $(\mathrm{p}<0,001)$. TB patients are often unemployed for a long time. If TB patients are employed, they commonly have lower-skilled jobs and lower salary level. The unemployed have 6.6 times higher risk of developing TB than the employed $-\mathrm{OR}=6.60(95 \% \mathrm{CI}=4.98$ to $8.7, \mathrm{p}<0.001)$. This result is generally similar to the data obtained in other countries that show higher level of unemployment among those who have TB, compared with those who do not have the disease $[10,13,21]$. Risk estimate of the unemployed $(\mathrm{OR}=6.6)$ is relatively similar to the result obtained in Russia [22] (OR $=6.1)$, as well as in Estonia [23] data $(\mathrm{OR}=5.1)$.

TB patients are characterized by a lower education level than the general population. $35.4 \%$ of TB patients have primary education ( 9 years) $(2.7 \%$ of the general population have primary education $(p<0.001))$. The results of other studies also show that TB patients have comparatively lower educational levels $[3,13]$.

Housing conditions of TB patients are usually poorer. TB patients more often have older housing $(\mathrm{p}<0.001)$, uncomfortable living conditions $(\mathrm{p}=0.005)$, smaller number of rooms $(\mathrm{p}<0.001)$ and smaller total area of housing $(\mathrm{p}=0.015)$. If compared to the general population, accommodation of TB patients is less often equipped with a central sewerage $(\mathrm{p}<0.001)$, hot and cold water supply $(p<0.001)$, toilet and bathroom $(p<0.001)$. Households of TB patients have wood-burning heating systems more often than central heating systems $(\mathrm{p}<0.001)$.

Having housing area of less than $15 \mathrm{~m}^{2}$ per one family member is a potential risk factor of TB - risk of developing TB is 1.8 times higher $(\mathrm{OR}=1.84,95 \% \mathrm{CI}=1.25$ to $2.69, \mathrm{p}$ $=0.002$ ) for people having housing area below $15 \mathrm{~m}^{2}$ than for people having wider housing area. Such low result can be explained by the fact that there is no correlation between monthly income per family member and the total living area, number of rooms and housing area per family member $\left(r_{s}=0.061 ; r_{s}=0.023 ; r_{s}=0.067\right.$ respectively $)$. It means that housing area is actually not a poverty indicator in Latvia.

There are more homeless people, as well people dwelling in non-residential areas like wagons, sheds or other inappropriate shelters among TB patients $(8.5 \%)$ than among the general population in Latvia $(0,226 \%, \mathrm{p}<0.001)$. TB risk is 28.7 times higher, if a person is homeless $-\mathrm{OR}=$ $28.65(95 \% \mathrm{CI}=22.35$ to $36.72, \mathrm{p}<0.001)$. This is a much higher score compared to the results of the Polish study [28] $(\mathrm{OR}=7.8)$. The difference in results may be due to the fact that there are $4.3 \%$ of the homeless people among the TB patients in the Polish study, whereas in Latvia the number of the homeless people among the TB patients is higher $-8.5 \%$.

Imprisonment status is a significant risk factor - there are more persons who had been imprisoned among TB patients $(18.8 \%)$ than among the general population $(0.8 \%$, $\mathrm{p}<0.001$ ). Imprisonment is a very significant TB risk factor - risk of developing TB is 27.6 times higher for persons who had been imprisoned $(\mathrm{OR}=27.57,95 \% \mathrm{CI}=18.82$ to 40.38 , $\mathrm{p}<0.001)$ than for individuals who had never been imprisoned.

The impact of the imprisonment on TB in Latvia is much higher, compared to the results of the study in Samara (Russia) [22] ( $\mathrm{OR}=12.5)$. The difference in results may attributed to the imprisonment statistics in these two countries. The total number of the persons that had been imprisoned comprises $0.8 \%$ of the population in Latvia, while in Russia this number is much higher $-3.6 \%$ of the population had been imprisoned at least once [50].

\subsection{Psychosocial Risk Factors}

The results show that psychological health of TB patients is worse, if compared to the general population. TB patients more often experience stress $(16.2 \%, \mathrm{p}<0.001)$, symptoms of depression $(24.8 \%, \mathrm{p}<0.001)$ and more often have suicidal thoughts $(7.2 \%, \mathrm{p}<0.001)$, if compared to the general population $(8.8 \%, 10.4 \%$ and $0.8 \%)$.

Bad psychological health is a statistically significant indicator, but not a very important risk factor - for persons having bad psychological health, the risk of TB is 4.15 times higher $-\mathrm{OR}=4.15(95 \% \mathrm{CI}=2.81$ to $6.12, \mathrm{p}<0.001)$, if 
compared to the general population.

However, in terms of social exclusion, there are no statistically significant differences between TB patients and the general population - social exclusion has no statistically significant impact $(\mathrm{p}>0.05)$ on the risk of TB.

\subsection{Lifestyle Risk Factors}

There are more smokers $(72.3 \%)$ among TB patients than in the society $(40.1 \%, \mathrm{p}<0.001)$. TB patients on average start smoking earlier $(\mathrm{M}=17.6 \pm 5.6$ years $(\mathrm{SD}))$ than the general population $(\mathrm{M}=25.3 \pm 10.3$ years $(\mathrm{SD}), \mathrm{p}<0.001)$. Long-term smoking is also more common among TB patients $-46.4 \%$ of TB patients smoke for 20 years and more ( $25.3 \%$ among the general population, $\mathrm{p}<0.001$ ).

However, TB patients are more worried about negative impact of smoking on health $(51.7 \%$ vs $38.9 \%, \mathrm{p}<0.001)$; they have decided to quit smoking more often and quicker $(43.4 \%$ vs $26.1 \%, \mathrm{p}<0.001)$ and have tried to give up smoking $(37.0 \%$ vs $13.2 \%, \mathrm{p}<0.001)$ more likely than the general population. Main reasons for giving up smoking are health problems $(22 \%)$ and desire to avoid TB (16\%); economic reasons take the third place (14\%). For the general population economic reasons $(13.0 \%)$ are the most important reason for quitting smoking. More than half of TB patients $(56.1 \%)$ begun to smoke less or quitted smoking during the TB treatment.

The risk of getting TB is 5.6 times higher for persons who used to smoke every day or time to time, compared to non-smokers $-\mathrm{OR}=5,6(95 \% \mathrm{CI}=4,0$ to $7,9, \mathrm{p}<0,001)$. These data are consistent with the results of other studies overall number of smokers is larger among TB patients, if compared to the general population. TB patients on average start smoking earlier and smoke for longer period. The risk of getting TB, if a person smokes, is 5.6 times higher in Latvia - this complies with the interval estimated by the French scientist K. Slama (2.3-9.3) [38]. However, the risk in Latvia is higher, if compared to other European countries (in Estonia the risk of getting TB, if the person smokes, is 4.6 times higher [23], in Spain - 2.1 times higher [40], while in Poland smoking is not recognized to be a statistically significant risk factor [28]). This can be related to the overall smoking tendency in Latvia $-35.5 \%$ of the Latvian population were regular smokers in 2012 - the number of smokers in Latvia is higher than in Estonia, Lithuania, Finland [51] and almost the higher among all European countries [52].

Use of alcohol is another risk factor - TB patients consume alcohol more often than population in Latvia. $46.9 \%$ of TB patients use alcohol at least once in a week; among the general population this number is lower $-30.3 \%$, $\mathrm{p}<0.001$. TB patients consume beer more often and in larger quantities $(p<0.001)$; the same can be related to the consumption of the strong alcohol ( $p<0.001)$, however the consumption of wine occurs less frequently $(\mathrm{p}<0.001)$.

The risk of developing TB is 2.0 times higher for those who use alcohol at least once a week than for those who consume alcohol less frequently $(\mathrm{OR}=2.0,95 \% \mathrm{CI}=1.5$ to $2.7, \mathrm{p}<0.001)$. This tendency is similar to the results obtained elsewhere - use of alcohol generally contributes to higher risk of developing TB. The research studies by K. Lönnroth show that the risk of developing TB in case of alcohol abuse is on average three times higher [53]; the results in Estonia show that the risk is much higher (15.0 times) [23]. The ratio in Latvia is similar to the results obtained in India, where the risk level is estimated to be 2.1 [39].

The number of drug addicts is higher among TB patients than among the general population. $12.0 \%$ of TB patients have tried drugs once or twice $(3.5 \%$ among the general population in Latvia), but $15.7 \%$ are using or have used drugs several times $(1.3 \%$ among the general population in Latvia). For persons who have tried drugs at least once, the risk of developing TB is 7.6 times higher than for those who have never tried drugs $-\mathrm{OR}=7.61(95 \% \mathrm{CI}=5.77$ to 10,03 , $\mathrm{p}<0.001$ ); this figure is lower, if compared to Russia, where the risk is estimated to be 8.7 times higher [22]. In Estonia drug use is not a statistically significant risk factor of TB [23].

The habit of skipping breakfast has an impact on risk of developing TB (Wald $=42.952 ; \mathrm{p}<0.001$ ). 67.4\% TB patients have habit of eating breakfast regularly; the number of persons having habit of eating breakfast is larger among the general population $-85.0 \%,(p<0.001)$.

Comparing BMI of patients with BMI of the persons from the general population, it is obvious that overweight is not typical for TB patients; TB patients are characterized as having underweight $(20.9 \%)$ and normal weight $(65.7 \%)$. The percentage of persons in the general population having underweight is $2.2 \%$ and the percentage of those having normal weight is $46.6 \%, \mathrm{p}<0.001)$. Underweight persons have 12 times higher risk of $\mathrm{TB}-\mathrm{OR}=12.01(95 \% \mathrm{CI}=$ 8.17-17.65, $\mathrm{p}<0.001)$. For instance, in Estonia the risk of developing TB, if the person is underweight, is just two times higher [23]. The current study also additionally detected that employment status has a moderate impact $\left(\mathrm{r}^{2}=0.017, \beta=0.129, \mathrm{p}<0.001\right)$ on the biological risk factor BMI that has a primary impact on TB.

\subsection{Biological Risk Factors}

The results show that there are more HIV infected persons (11.4\%) among TB patients than among the general population $(0.3 \%, \mathrm{p}<0.001)$. HIV presence is the strongest TB risk factor $-\mathrm{OR}=40.11(95 \% \mathrm{CI}=32.23$ to 49.92 , $p<0.001$ ). The results of others studies show that this risk usually varies between 6 and 26 [13]; WHO provides the usual range of 21-34 [45]. It means that the risk of developing TB, if a person is HIV positive, is the highest in Latvia.

The second biological risk factor - diabetes statistically significantly does not differ between TB patients (4.3\%) and the general population in Latvia $(3.1 \%, p=0.247)$. It is different from the results of the studies in other countries 
displaying statistical significance of this risk factor $[3,10$, 19, 22].

In addition, the results show that males are more affected by TB $(69.4 \%, \mathrm{p}<0.001)$ than females; males have 2.8 times higher risk to get TB than females $-\mathrm{OR}=2.82(95 \%$ $\mathrm{CI}=2.20$ to $2.62, \mathrm{p}<0.001)$. Age, as a separate predictor, does not significantly contribute to the increased risk of developing $\mathrm{TB}-\mathrm{r}_{\mathrm{s}}=0.060, \mathrm{p}=0.001$.

\subsection{Summary of Risk Conditions and Risk Factors}

The impact (OR) of each risk condition and risk factor was determined separately (see the Table 1).

The presence of HIV is the most important biological risk factor. The risk of developing TB for a virus-positive individual is 40.1 times higher than for an individual without the virus.

Homelessness is the second strongest TB risk condition. If a person is homeless, the risk of getting TB is 28.7 times higher than for an individual who dwells in a house, an apartment or in a jointly-inhabited area.

Another very important risk condition is imprisonment - if an individual had been imprisoned, the risk of getting TB is 27.6 times higher than for a person who had never been imprisoned.

The lifestyle factor - underweight is the fourth important risk factor of developing TB. For persons who are underweight ( $<18.5$ points) the risk of getting TB is 12 times higher than for people with normal weight or overweight.

Hence, HIV-positive individuals, homeless, having been imprisoned, as well as those who are underweight, are subjected to comparatively higher risk of TB.

In order to attribute the impact of the risk conditions and risk factors to the society, it is essential to consider additional indicator - PAF (\%). This indicator is calculated by taking into account the prevalence of risk factor in society and its importance on individual level.

PAF indicator significantly reduces relevance of the individual level risk factors (HIV, homelessness, imprisonment and underweight) to the society in general, due to low prevalence of these factors, PAF of HIV is $11.3 \%$, PAF of homelessness $-8.3 \%$ and PAF of imprisonment $-18.1 \%$ of TB cases. At the same time, PAF significantly increases the importance of smoking, making it the most important risk factor of TB $-59.3 \%$ of TB disease cases can be attributed to smoking. The second most important risk condition is income level per family member $-53.1 \%$ of TB cases in the society are related to insufficient income. The third most important risk factor is gender (male), which PAF indicator ranks as the most important risk factors of the society. This can be explained by the high number of males among TB patients.

Table 1. Summary of TB risk conditions and risk factors

\begin{tabular}{|c|c|c|c|c|}
\hline Conditions and factors & OR $(95 \%$ CI $)$ & P-value & Prevalence & PAF \\
\hline \multicolumn{5}{|c|}{ Level 2. Living and working risk conditions } \\
\hline 1. Homelessness & $28.6(22.4-36.7)$ & $<0.001$ & $0.33 \%$ & $8.33 \%$ \\
\hline 2. Experience of imprisonment & $27.6(18.8-40.4)$ & $<0.001$ & $0.83 \%$ & $18.13 \%$ \\
\hline 3. Income $\$ 0-200$ per family member & $6.8(5.1-9.1)$ & $<0.001$ & $19.20 \%$ & $53.13 \%$ \\
\hline 4. Unemployment & $6.6(5.0-8.7)$ & $<0.001$ & $17.00 \%$ & $40.42 \%$ \\
\hline 5. Housing area $<15 \mathrm{~m}^{2}$ per person & $1.8(1.3-2.7)$ & 0.002 & $19.20 \%$ & $13.60 \%$ \\
\hline 6. Born outside Latvia & $0.8(0.6-1.1)$ & 0.225 & $14.60 \%$ & $-3.05 \%$ \\
\hline \multicolumn{5}{|c|}{ Lever 3. Psychosocial risk factors } \\
\hline 1. Bad psychological health & $4.15(2.8-6.1)$ & $<0.001$ & $5.30 \%$ & $14.37 \%$ \\
\hline \multicolumn{5}{|c|}{ Level 4. Lifestyle risk factors } \\
\hline 1. Underweight & $12.0(8.2-17.7)$ & $<0.001$ & $2.20 \%$ & $19.13 \%$ \\
\hline 2. Experience of drug using & $7.6(5.8-10.0)$ & $<0.001$ & $4.70 \%$ & $24.14 \%$ \\
\hline 3. Regular or occasional smoking & $5.6(4.0-7.9)$ & $<0.001$ & $40.10 \%$ & $59.34 \%$ \\
\hline 4. Skipping breakfast & $2.7(2.0-3.7)$ & $<0.001$ & $15.00 \%$ & $20.72 \%$ \\
\hline 5. Use of alcohol $\geq 1$ per week & $2.0(1.5-2.7)$ & $<0.001$ & $30.30 \%$ & $33.79 \%$ \\
\hline \multicolumn{5}{|c|}{ Core factors. Biological risk factors } \\
\hline 1. HIV positive & $40.1(32.2-49.9)$ & $<0.001$ & $0.33 \%$ & $11.35 \%$ \\
\hline 2. Male & $2.82(2.2-2.6)$ & $<0.001$ & $44.60 \%$ & $44.85 \%$ \\
\hline 3. Diabetes & $1.42(0.8-2.6)$ & 0.249 & $3.10 \%$ & $8.19 \%$ \\
\hline
\end{tabular}




\subsection{Multifactor Model}

Multifactor analysis focuses on all risk factors and risk conditions simultaneously, considering their mutual interplay. The impact of the risk factors and risk conditions is summarized in Table 2. Nagelkerke $\mathrm{R}^{2}$ of the model 0.443 .

Table 2. Risk factors and risk conditions of TB

\begin{tabular}{|c|c|c|c|c|}
\hline Risk factors & B & SE & Wald & P \\
\hline Gender & 0.166 & 0.25 & 0.432 & 0.511 \\
\hline Age & 0.037 & 0.01 & 13.460 & $<0.001$ \\
\hline BMI & -0.375 & 0.04 & 96.955 & $<0.001$ \\
\hline Drug use & 1.162 & 0.18 & 43.314 & $<0.001$ \\
\hline Smoking & 0.141 & 0.14 & 1.097 & 0.295 \\
\hline Alcohol use & -0.088 & 0.08 & 1.118 & 0.290 \\
\hline Psychological health & -1.241 & 0.57 & 4.782 & 0.029 \\
\hline Habit of eating breakfast & 0.906 & 0.23 & 15.204 & $<0.001$ \\
\hline Employment & 1.019 & 0.24 & 17.450 & $<0.001$ \\
\hline Income & 0.179 & 0.17 & 1.134 & 0.287 \\
\hline Education & 0.234 & 0.11 & 4.407 & 0.036 \\
\hline
\end{tabular}

The results show that the most important predictor is BMI (Wald $=96.96, p<0.001)$. Second strongest predictor that increases the risk of TB is drug use (Wald $=43.31, p<$ 0.001 ), but the condition of unemployment takes the third place in terms of impact on TB (Wald $=17.45, \mathrm{p}<0.001)$.

BMI has the most significant impact on the onset of TB. The additional analysis shows that predictors (age, gender, employment, diet, physical condition, and physical activities) have minor impact on changes of BMI (Adjusted $\left.\mathrm{R}^{2}=0.167\right)$. BMI is mostly affected by biological risk factors - age $(\beta=0.371, p<0.001)$ and gender $(\beta=0.065$, $\mathrm{p}=0.003$ ); also employment has impact on BMI (BMI is higher of the individuals who are employed $)(\beta=-0.080, p$ $=0.001)$. Impact of diet on BMI is very weak or zero; there is also no statistically significant impact of physical condition $(p>0.05)$ and physical activities $(p>0.05)$ on BMI. This means that BMI should be more analysed as independent biological risk factor, and not as result of individual's lifestyle.

\section{Conclusions and Recommendations}

Applying Four-layer health determinant model to the analysis of risk factors and conditions of TB, several high importance factors appear. Firstly, there are second level factors that can be referred to as the risk conditions inappropriate living conditions, unemployment, homelessness and imprisonment. Prevalence of TB risk factors is affected by these risk conditions. Secondly, individual lifestyle risk forth level factors - underweight and drug use are factors of high importance. As it is known, factors on these levels have an impact on the immune system disorders. Finally, HIV infection that can also be described as core human biological risk factor, is a factor that contributes to TB causation.

A comparatively narrow circle of persons belonging to the risk group of TB is usually targeted in TB prevention programmes. Conventionally, these risk groups are homeless persons, immigrants, persons having low income level, individuals who smoke and HIV-infected persons. The current study points out additional factors that contribute to onset of TB - BMI, habit of skipping breakfast and bad psychological health. Contrary to the common stereotype, harmful habits, such as smoking, alcohol use and drug use, are less important risk factors, if compared to low BMI. Current TB prevention programmes neglect BMI as a potential risk factor of TB. Physicians or other healthcare staff should also emphasize the impact of the unhealthy diet on the risk of TB.

The analysis also shows that the role of income in TB causation has been exaggerated, as the most important risk condition is unemployment, not income. These two risk conditions are associated with each other, but unemployment should be considered as a primary risk condition. Absence of work negatively influences psychological health and creates additional stress; it also encourages habits that are harmful to health - smoking, alcohol and drug use. Employment status has a mediated effect on TB. Therefore, TB prevention programmes should more focus on the unemployed persons - educating about symptoms of TB, negative consequences of heath damaging habits, like smoking, alcohol and drug use, informing about examination and treatment options, as well as providing psychological support.

As imprisonment is an important risk condition, impact of this risk factor on TB should be minimized programmes of resocialization should enclose information about TB symptoms; the same relates to programmes targeted to rehabilitation from alcoholism, drug addiction and HIV.

TB prevention programmes should also stress the importance of social workers who can provide support to TB patients in case of psychological problems during and after the treatment.

The further research on TB should involve studies using qualitative methods, as these studies help understand patient's perspective and subjective illness experience, as well as give deeper insight into social, economic and psychological problems of the patients. This would give a comprehensive insight into the problem, helping target prevention and elimination of TB more precisely.

\section{REFERENCES}

[1] L. Vīksna, Infekcijas slimības, Rīga: Medicīnas apgāds, 2011, p. 590. (in Latvian) 
[2] J.-P. Millet, A. Moreno, L. Fina, L. Del Baño, A. Orcau, P. G. De Olalla and J. Caylà, "Factors that influence current tuberculosis epidemiology," European Spine Journal, vol. 22, no. 4, pp. 539-548, June 2012.

[3] P. Narasimhan, J. Wood, R. M. Chandini and D. Mathai, "Risk Factors for Tuberculosis," Pulmonary Medicine, vol. 2013, pp. 1-11, 6 January 2013.

[4] WHO, "Global Tuberculosis Report 2013," World Health Organization, Geneva, 2013.

[5] WHO, "Global tuberculosis report 2014," World Health Organization, Geneva, 2014.

[6] WHO, "Global tuberculosis report, 2015," World Health Organization, Geneva, 2015.

[7] WHO, "Tuberculosis," March 2014. [Online]. Available: http://who.int/mediacentre/factsheets/fs 104/en/.

[8] WHO, "Forty-fourth World Health Assembly. WHA44/1991/REC/1," World Health Organization, Geneva, 1991.

[9] SPKC, "Dati par saslimstību ar tuberkulozi" 2014. [Online]. Available: http://www.spkc.gov.lv/tuberkuloze/ Latvian.

[10] K. Lönnroth, E. Jaramillo, B. G. Williams, C. Dye and M. Raviglione, "Drivers of tuberculosis epidemics: The role of risk factors and social determinants," Social Science and Medicine, vol. 68, no. 12, pp. 2240-2246, June 2009.

[11] А. В. Мордык, М. А. Плеханова, Н. В. Соботюк и Е. А. Цыганкова, «Социальные и эпидемиологические факторы риска развития туберкулеза у детей раннего возраста,» Российский педиатрический журнал, № 3, pp. 56-59, 2011. (in Russian)

[12] L. G. Wilson, "Medicine, population and tuberculosis," International Journal of Epidemiology, vol. 34, p. 521-524, 2005.

[13] C. Lienhardt, "From exposure to disease: The role of environmental factors in susceptibility to and development of tuberculosis," Epidemiologic Reviews, vol. 23, no. 2, pp. 288-301, 2001

[14] WHO, "Global health risks: mortality and burden of disease attributable to selected major risks." WHO Press, Geneva, 2009.

[15] G. Dahlgren and M. Whitehead, "Policies and strategies to promote social equity in health," Institute for Future Studies, Stockholm, 1991.

[16] J. VanLeeuwen, D. Waltner-Toews, T. Abernathy and B. Smit, "Evolving Models of Human Health Toward an Ecosystem Context," Ecosystem Health, vol. 5, no. 3, p. 204-219, September 1999.

[17] N. Arinaminpathy and C. Dye, "Health in financial crises: economic recession and tuberculosis in Central and Eastern Europe," Journal of the Royal Society Interface, vol. 7, no. 52, p. 1559-1569, 6 November 2010.

[18] N. W. Schluger, R. Huberman, N. Wolinsky, R. Dooley, W. Rom and R. Holzman, "Tuberculosis infection and disease among persons seeking social services in New York City," The International Journal of Tuberculosis and Lung Disease, vol. 1, no. 1, pp. 31-37, February 1997.
[19] A. Jurcev-Savicevic, R. Mulic, B. Ban, K. Kozul, L. Bacun-Ivcek, J. Valic, G. Popijac-Cesar, S. Marinovic-Dunatov, M. Gotovac and A. Simunovic, "Risk factors for pulmonary tuberculosis in Croatia: a matched case-control study," BMC Public Health, vol. 13, 2013.

[20] E. Rapiti, V. Fano, F. Forastiere, N. Agabiti, S. Geraci, M. Scano, F. Alichino and D. Rinnenburger, "Determinants of tuberculosis in an immigrant population in Rome: a case-control study," The International Journal of Tuberculosis and Lung Disease, vol. 2, no. 6, pp. 479-483, 1998.

[21] В. А. Подгаева, Д. Н. Голубев, И. А. Черняев и П. Л. Шулев, «Влияние уровня жизни на показатели, отражающие эпидемиологическую ситуацию по туберкулезу на Урале,» Туберкулез и болезни легких, № 8, pp. 8-10, 2011. (in Russian)

[22] R. Coker, M. McKee, R. Atun, B. Dimitrova, E. Dodonova, S. Kuznetsov and F. Drobniewski, "Risk factors for pulmonary tuberculosis in Russia: case-control study," British Medical Journal, vol. 332, pp. 85-87, 12 January 2006.

[23] M. Tekkel, M. Rahu, H.-M. Loit and A. Baburin, "Risk factors for pulmonary tuberculosis in Estonia," The International Journal of Tuberculosis and Lung Disease, vol. 6, no. 10, pp. 887-894, 2002.

[24] W. M. Jakubowiak, E. M. Bogorodskaya, E. S. Borisov, D. I. Danilova and E. K. Kourbatova, "Risk factors associated with default among new pulmonary TB patients and social support in six Russian regions," The International Journal of Tuberculosis and Lung Disease, vol. 11, no. 1, pp. 46-53, 1 January 2007.

[25] В. Б. Авдентова, Е. М. Белиловский и С. Е. Борисов, «Факторы, оказывающие влияние на окончательные результаты лечения больных туберкулезом легких,» Туберкулез и болезни легких, pp. 17-18, 2011. (In Russian)

[26] Canadian TB Committee, "Housing conditions that serve as risk factors for tuberculosis infection and disease," Canada Communicable Disease Report, vol. 33, p. 1-13, 1 October 2007.

[27] M. Clark, P. Riben and E. Nowgesic, "The association of housing density, isolation and tuberculosis in Canadian First Nations communities," International Journal of Epidemiology, vol. 31, no. 5, pp. 940-945, 25 February 2002.

[28] J. Romaszko, A. Buciński, R. Wasiński, A. Rosłan and K. Bednarski, "Incidence and risk factors for pulmonary tuberculosis among the poor in the northern region of Poland," The International Journal of Tuberculosis and Lung Disease, vol. 12, no. 4, pp. 430-435, April 2008.

[29] UK HPA, "Tuberculosis in the UK: Annual report on tuberculosis surveillance in the UK," Health Protection Agency, London, 2013.

[30] А. Л. Санников, «Социально-гигиенические проблемы туберкулеза в уголовно-исполнительной системе,» Проблемы туберкулеза, № 4, pp. 7-10, 1998. (In Russian)

[31] B. A. Issa, A. D. Yussuf and S. I. Kuranga, "Depression comorbidity among patients with tuberculosis in a university teaching hospital outpatient clinic in Nigeria," Mental Health in Family Medicine, vol. 6, no. 3, p. 133-138, September 2009. 
[32] S. Mobar and A. Sharma, "Stigma and Social Exclusion among Tuberculosis Patients," The International Journal of Health, Wellness and Society, vol. 1, no. 4, pp. 119-140, 2011.

[33] A. Pachi, D. Bratis, G. Moussas and A. Tselebis, "Psychiatric Morbidity and Other Factors Affecting Treatment Adherence in Pulmonary Tuberculosis Patients," Tuberculosis Research and Treatment, vol. 2013, pp. 1-37, 15 April 2013.

[34] A. Adem, M. Tesfaye and M. Adem, "The Prevalence and Pattern of Depression in Patients with Tuberculosis on Follow-up at Jimma University Specialized Hospital and Jimma Health Center," Medicine Science, vol. 3, no. 1, pp. 955-968, January 2013.

[35] K. Peltzer, P. Naidoo, G. Matseke, J. Louw, G. Mchunu and B. Tutshana, "Prevalence of psychological distress and associated factors in tuberculosis patients in public primary care clinics in South Africa," BMC Psychiatry, vol. 12, no. 89, pp. 1-9, 2012.

[36] M. Kruijshaar, M. Lipman, M.-L. Essink-Bot, S. Lozewicz, D. Lozewicz, S. Dart, H. Maguire and I. Abubakar, "Health status of UK patients with active tuberculosis," The International Journal of Tuberculosis and Lung Disease, vol. 14, no. 3, pp. 296-302, March 2010.

[37] M. Adina, O. Necrelescu and C. Bondor, "Depressive syndrome, anxiety and illness perception in Tuberculosis patients," Recent Researches in Modern Medicine, pp. 243-248, 2011.

[38] K. Slama, C.-Y. Chiang, D. Enarson, K. Hassmiller, A. Fanning, P. Gupta and C. Ray, "Tobacco and tuberculosis: a qualitative systematic review and meta-analysis," The International Journal of Tuberculosis and Lung Disease, vol. 11, no. 10, pp. 1049-1061, October 2007.

[39] C. Kolappan, P. Gopi, R. Subramani and P. Narayanan, "Selected biological and behavioural risk factors associated with pulmonary tuberculosis," The International Journal of Tuberculosis and Lung Disease, vol. 11, no. 9, pp. 999-1003, September 2007.

[40] M. N. Altet-Gómez, J. Alcaide, P. Godoy, M. Romero and I. Hernández del Rey, "Clinical and epidemiological aspects of smoking and tuberculosis: a study of 13038 cases," The International Journal of Tuberculosis and Lung Disease, vol. 9, no. 4, pp. 430-436, 2005.

[41] R. Doll, "Risk from tobacco and potentials for health gain," The International Journal of Tuberculosis and Lung Disease, vol. 3, no. 2, pp. 90-99, February 1999.

[42] D. Yach, "Partnering for better lung health: improving tobacco and tuberculosis control," The International Journal of Tuberculosis and Lung Disease, vol. 4, no. 8, pp. 693-697, August 2000.

[43] J. Cegielski and D. N. McMurray, "The relationship between malnutrition and tuberculosis: evidence from studies in humans and experimental animals," The International Journal of Tuberculosis and Lung Disease, vol. 8, no. 3, pp. 286-298, 1 March 2004.

[44] H. Hemilä, J. Kaprio, P. Pietinen, D. Albanes and O. P. Heinonen, "Vitamin $\mathrm{C}$ and other compounds in vitamin $\mathrm{C}$ rich food in relation to risk of tuberculosis in male smokers," American Journal of Epidemiology, vol. 150, no. 6, pp. 632-416, 1999.

[45] WHO, "Global Tuberculosis Control 2011," World Health Organization, Geneva, 2011.

[46] I. Pudule, D. Grīnberga, B. Velika, I. Gavare and A. Villeruša, Latvijas iedzīvotāju veselību ietekmējošo paradumu pētijums, 2012, Rīga: Slimību profilakses un kontroles centrs, 2013, p. 41. (In Latvian)

[47] CSP, Ienākumi un dz̄ives apstākḷi Latvijā 2012.gadā, Rīga: LR Centrālā statistikas pārvalde, 2013, p. 70. (In Latvian)

[48] S. Sniķere, M. Trapencieris, I. Korol̦eva, I. Mieriņa, S. Priekule, A. Aleksandrovs and M. Jankovskis, Atkarību izraisošo vielu lietošanas izplatība iedzīvotāju vidū, Rīga: Slimību profilakses un kontroles centrs, 2012. (In Latvian)

[49] LU FSI, BICEPS, SPI, Bezdarba un sociālās atstumtības iemesli un ilgums, Rīga: LR Labklājības ministrija, 2007, p. 472. (In Latvian)

[50] В. Радченко, «Российская газета,» 2008. Available: http://www.rg.ru/2008/09/02/radchenko.html. (In Rusian).

[51] R. Prättälä, S. Helakorpi, N. Sipilä, R. Sippola and K. Sääksjärvi, "Social Determinants of Health Behaviours: Finbalt Health Monitor 1998-2008," National Institute for Health and Welfare, Helsinki, 2011.

[52] WHO, "Tobacco," 2010. [Online]. Available: http://apps.who.int/gho/data/view.main.1805.

[53] K. Lönnroth, B. G. Williams, S. Stadlin, E. Jaramillo and C. Dye, "Alcohol use as a risk factor for tuberculosis - a systematic review," BMC Public Health, vol. 8, pp. 289-301, 14 August 2008. 